\title{
The Determination of the Relationship between Somatotypes and Speed of Sub- Elite Athletes
}

\author{
İran MARANGOZ \\ 'Ahi Evran University, School of Physical Education and Sports, Krrşehir, Turkey \\ Email:imarangoz@ahievran.edu.tr Tel:5066322100
}

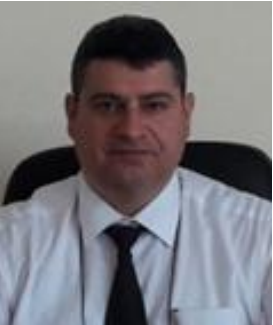

\begin{abstract}
This study aims to analyze the relationship between somatotypes and speed of 180 male sub-elite athletes aged between 18 and 25. Athletes were divided into two categories as balanced group (balanced somatotype groups) and randomly selected groups (groups outside balanced somatotypes groups) based on their somatotype structures. The arithmetic means and standard deviations of groups are $(\mathrm{n}=30) 21.95 \pm 2.80$ years of age, height $168.40 \pm 2.62 \mathrm{~cm}$, weight $69.20 \pm 5.26 \mathrm{~kg}$ in balanced endomorph group, $(\mathrm{n}=30) 21.60 \pm 3.15$ years of age, height $170.25 \pm 6.39$ $\mathrm{cm}$, weight $67.25 \pm 6.09 \mathrm{~kg}$ in balanced mesomorph group, and $(\mathrm{n}=30) 20.40 \pm 1.46$ years of age, height $175.10 \pm 5.02 \mathrm{~cm}$, and weight $60.05 \pm 5.09 \mathrm{~kg}$ in balanced ectomorph group. On the other hand, the same values are $(\mathrm{n}=30) 21.35 \pm 2.30$ years of age, height $160.10 \pm 2.20 \mathrm{~cm}$, and weight $69.30 \pm 5.70 \mathrm{~kg}$ in random endomorph group, $(\mathrm{n}=30) 21.36 \pm 2.40$ years of age, height $169.24 \pm 2.21$ $\mathrm{cm}$ and weight $65.40 \pm 3.25 \mathrm{~kg}$ in random mesomorph groups, and $(\mathrm{n}=30) 20.50 \pm 1.85$ years of age, height $176.15 \pm 3.30 \mathrm{~cm}$ and weight $70.10 \pm 4.45 \mathrm{~kg}$ in random ectomorph group. The measurement data were analyzed using SPSS 2.0 package program for Windows. Somatotype calculations were done in SOMATOTURK Calculation Program. The statistical analysis demonstrated that a highly positive significant correlation $(\mathrm{p}<0.001)$ was found between balanced somatotype groups (balanced endomorph, mesomorph and ectomorph) and randomly selected somatotype groups (random endomorph, mesomorph and ectomorph).
\end{abstract}

Keywords: Sub-elite athletes, Somatotypes, Speed.

Citation | İran MARANGOZ (2018). The Determination of the Relationship between Somatotypes and Speed of Sub-Elite Athletes. Asian Journal of Education and Training, 4(3): 220-223. History:

Received: 14 May 2018

Revised: 4 June 2018

Accepted: 6 June 2018

Published: 8 June 9018

Licensed: This work is licensed under a Creative Commons

Attribution 3.0 License (cc) EY

Publisher:Asian Online Journal Publishing Group
Funding: This study received no specific financial support.

Competing Interests: The author declares that there are no conflicts of interests regarding the publication of this paper.

Transparency: The author confirms that the manuscript is an honest, accurate, and transparent account of the study was reported; that no vital features of the study have been omitted; and that any discrepancies from the study as planned have been explained.

Ethical: This study follows all ethical practices during writing.

\section{Contents}

1. Introduction

3. Findings

4. Discussion.

References. 


\section{Introduction}

It is not possible to reach a certain level of performance without physical properties suitable to the sports that an individual performs (Marangoz and Polat, 2017). Body structure is one of the factors influencing performance. Physical properties or body structures affect an individual's physiological capacity (Hazır and Açıada, 2002). Strength and condition training are key elements in terms of reaching a high speed. Athletes need to effectively reach a maximum speed running speed for a successful performance (Murphy et al., 2003). Success requires a fast start, reaching the highest running speed as possible and keeping it for a certain duration (Delecluse et al., 1995; Johnson and Buckley, 2001) which is influenced by anthropometric, metabolic, neural and biomechanical factors (Abe et al., 2001; Ross et al., 2001).

\section{Materials and Method}

180 male sub-elite athletes aged between 18 and 25 and living in Kırşehir and Kahramanmaraş provinces of Turkey voluntarily participated in this study. They were divided into two categories as balanced group (balanced somatotype groups) and randomly selected groups (groups outside balanced somatotypes groups) based on their somatotype structures. The somatotypes and speed of sub-elite athletes were measured. Average means and standard deviations are given below:

Balanced endomorph group $(\mathrm{n}=30) 21.95 \pm 2.80$ years of age, $168.40 \pm 2.62 \mathrm{~cm}$ height, $69.20 \pm 5.26 \mathrm{~kg}$ weight.

Balanced mesomorph group $(\mathrm{n}=30) 21.60 \pm 3.15$ years of age, $170.25 \pm 6.39 \mathrm{~cm}$ height, $67.25 \pm 6.09 \mathrm{~kg}$ weight.

Balanced ectomorph group ( $\mathrm{n}=30) 20.40 \pm 1.46$ years of age, $175.10 \pm 5.02 \mathrm{~cm}$ height, $60.05 \pm 5.09 \mathrm{~kg}$ weight.

Random endomorph group ( $\mathrm{n}=30) 21.35 \pm 2.30$ years of age, $160.10 \pm 2.20 \mathrm{~cm}$ height, $69.30 \pm 5.70 \mathrm{~kg}$ weight.

Random mesomorph group (n=30) $21.36 \pm 2.40$ years of age, $169.24 \pm 2.21 \mathrm{~cm}$ height, $65.40 \pm 3.25 \mathrm{~kg}$ weight.

Random ectomorph group $(\mathrm{n}=30) 20.50 \pm 1.85$ years of age, boy $176.15 \pm 3.30 \mathrm{~cm}$ height, $70.10 \pm 4.45 \mathrm{~kg}$ weight.

\subsection{Determination of Somatotypes}

The somatotype values of the participants were determined using Heath Carter method of somatotyping. Based on this method, body weight, height, biceps and calf circumference during flexion, humerus and femur breadth, triceps, subscapular, suprailiac and calf skinfold as well as following formulas (Ross and Marfell-Jones, 1991; Carter, 2002) are used to calculate somatotype values. In addition, "SOMATOTURK" program was used for calculations (Marangoz and Özbalcı, 2017).

\subsubsection{Determination of Endomorph}

$\mathrm{A}=$ triceps + subscapular + suprailiac

$\mathrm{B}=(170.18 /$ height $)$ (Adjustment coefficient for height)

Adjusted sum $\mathrm{X}=\mathrm{A} . \mathrm{B}$

Endomorph $=-0.7182+0.1451(\mathrm{X})-0.00068\left(\mathrm{X}^{2}\right)+0.0000014\left(\mathrm{X}^{3}\right)$

\subsubsection{Determination of Mesomorph}

Mesomorph $=(0.858 \mathrm{HB}+0.601 \mathrm{FB}+0.188 \mathrm{CAG}+0.161 \mathrm{CCG})-(0.131 \mathrm{H})+4.5$

\begin{tabular}{l|c|l}
\hline HB & $:$ & Humerus breadth $(\mathrm{cm})$ \\
\hline FB & $:$ & Femur breadth $(\mathrm{cm})$ \\
\hline CAG & $:$ & Arm circumference during flexion - Triceps skinfold /10 \\
\hline CCG & $:$ & Maximal calf circumference - Calf skinfold /10 \\
\hline H & $:$ & Height $(\mathrm{cm})$ \\
\hline
\end{tabular}

\subsubsection{Determination of Ectomorph}

Height and weight are calculated in $\mathrm{cm}$ and $\mathrm{kg}$, respectively. Height is divided by the cube root of weight to calculate HWR (HWR=height/cube root of weight). Ectomorph is calculated based on HWR value using one of the formulas below:

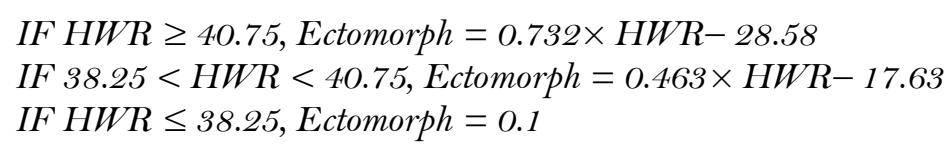

\subsection{0 and $20 \mathrm{~m}$ Speed Performance}

$10 \mathrm{~m}$ and $20 \mathrm{~m}$ speed performances were measured using a New Test 2000 photocell device. The athletes warmed up for 10 minutes prior to the test. The track closing time was recorded in milliseconds. The test was repeated twice following a full rest, and the best results were used in the study.

\subsection{Statistical Analyses}

In this study, which analyzes the relationship between speed and balanced/randomly selected endomorph, mesomorph and ectomorph groups of sub-elite athletes, Windows SPSS 22.0 package program was used for spearman correlation analysis with a significance level of 0.05 . 


\section{Findings}

\begin{tabular}{|c|c|c|c|c|c|c|}
\hline & \multicolumn{3}{|c|}{ BALANCED GROUPS } & \multicolumn{3}{|c|}{ RANDOM GROUPS } \\
\hline & $\begin{array}{l}\text { Endomorph } \\
\text { Group } \\
(\mathrm{n}=30) \\
\end{array}$ & $\begin{array}{l}\text { Mesomorph } \\
\text { Group } \\
(\mathrm{n}=30) \\
\end{array}$ & $\begin{array}{l}\text { Ectomorph } \\
\text { Group } \\
(\mathrm{n}=30)\end{array}$ & $\begin{array}{l}\text { Endomorph } \\
\text { Group } \\
(\mathrm{n}=30) \\
\end{array}$ & $\begin{array}{l}\text { Mesomorph } \\
\text { Group } \\
(\mathrm{n}=30)\end{array}$ & $\begin{array}{l}\text { Ectomorph } \\
\text { Group } \\
(\mathrm{n}=30)\end{array}$ \\
\hline & $\mathrm{x} \pm \mathrm{sd}$ & $\mathrm{x} \pm \mathrm{sd}$ & $\mathrm{x} \pm \mathrm{sd}$ & $\mathrm{x} \pm \mathrm{sd}$ & $\mathrm{x} \pm \mathrm{sd}$ & $\mathrm{x} \pm \mathrm{sd}$ \\
\hline Age (years) & $21.95 \pm 2.80$ & $21.60 \pm 3.15$ & $20.40 \pm 1.46$ & $21.35 \pm 2.30$ & $21.36 \pm 2.40$ & $20.50 \pm 1.85$ \\
\hline Height $(\mathrm{cm})$ & $168.40 \pm 2.62$ & $170.25 \pm 6.39$ & $175.10 \pm 5.02$ & $160.10 \pm 2.2$ & $169.24 \pm 2.21$ & $176.15 \pm 3.30$ \\
\hline Weight (kg) & $69.20 \pm 5.26$ & $67.25 \pm 6.09$ & $60.05 \pm 5.09$ & $69.30 \pm 5.70$ & $65.40 \pm 3.25$ & $70.10 \pm 4.45$ \\
\hline $10 \mathrm{~m}(\mathrm{sec})$ & $2.30 \pm 0.09$ & $1.90 \pm 0.18$ & $2.05 \pm 0.13$ & $2.63 \pm 0.14$ & $2.40 \pm 0.19$ & $2.26 \pm 0.18$ \\
\hline $20 \mathrm{~m}(\mathrm{sec})$ & $3.05 \pm 0.15$ & $2.40 \pm 0.29$ & $2.81 \pm 0.12$ & $3.25 \pm 0.16$ & $2.98 \pm 0.22$ & $2.99 \pm 0.14$ \\
\hline
\end{tabular}

$( \pm)$ (Mean and standard deviation)

\begin{tabular}{l|l|l|l|l|l|l} 
Table-2. The comparisons of 10m Pearson correlation analysis between balanced and randomly selected somatotype groups \\
\hline
\end{tabular}

Random Ectomorp

Table-3. The comparisons of $20 \mathrm{~m}$ Pearson correlation analysis between balanced and randomly selected somatotype groups

\begin{tabular}{|c|c|c|c|c|c|c|}
\hline & & $\begin{array}{l}\text { Balanced } \\
\text { Endomorph }\end{array}$ & $\begin{array}{l}\text { Random } \\
\text { Endomorph }\end{array}$ & $\begin{array}{l}\text { Balanced } \\
\text { Mesomorph }\end{array}$ & $\begin{array}{l}\text { Random } \\
\text { Mesomorph }\end{array}$ & $\begin{array}{l}\text { Balanced } \\
\text { Ectomorph }\end{array}$ \\
\hline Random Endomorph & $\mathrm{r}$ & $1.000^{* * * *}$ & - & - & - & - \\
\hline Balanced Mesomorph & $r$ & $1.000^{* * * *}$ & $1, .000^{* * * *}$ & - & - & - \\
\hline Random Mesomorph & $\mathrm{r}$ & $1.000^{* * * *}$ & $1.000^{* * * *}$ & $1, .000^{* * * *}$ & - & - \\
\hline Balanced Ectomorph & $\mathrm{r}$ & $1.000^{* * * *}$ & $1.000^{* * * *}$ & $1.000^{* * * *}$ & $1.000^{* * * *}$ & - \\
\hline Random Ectomorph & $\mathrm{r}$ & $1.000^{* * * *}$ & $1.000^{* * * * *}$ & $1.000^{* * * *}$ & $1.000^{* * * * *}$ & $1.000^{* * * * *}$ \\
\hline
\end{tabular}

Pearson correlation between balanced and randomly selected somatotype groups for $10 \mathrm{~m}$ and $20 \mathrm{~m}$ distance ranges were compared as shown in Table 2 and 3. The results indicate a very highly positive correlation with a significance level of $\mathrm{p}<0.001$ between balanced somatotype groups (balanced endomorph, mesomorph and ectomorph) and randomly selected somatotype groups (random endomorph, mesomorph and ectomorph) for $10 \mathrm{~m}$ and $20 \mathrm{~m}$ distance ranges.

3.5

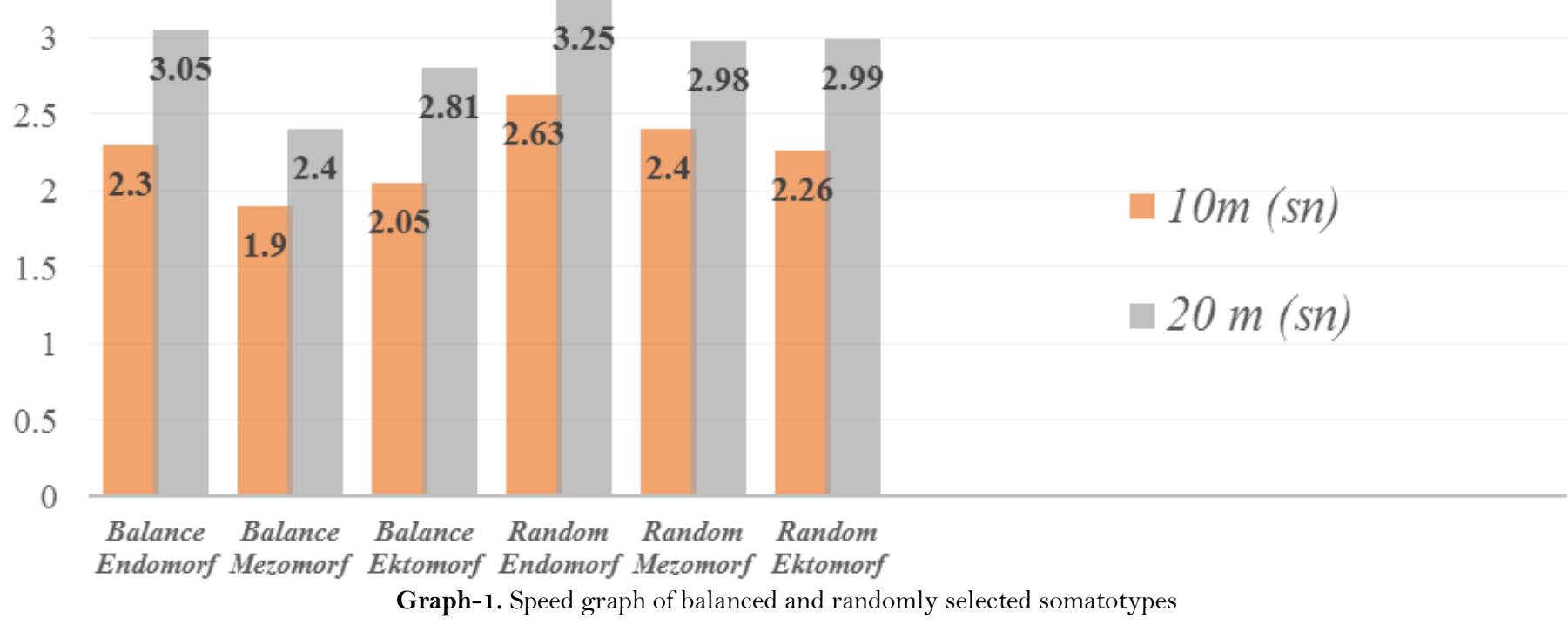

\section{Discussion}

Speed is the rate of change that enables a player to reach the highest speed within the shortest amount of time (Gambetta, 1996). In a study on 24 male sub-elite athletes (8 rugby players, 8 sprinters and 8 active athletes), 5$10 \mathrm{~m}$ test values of rugby players, sprinters and active athletes were measured as $0.71 \pm 0.09,0.68 \pm 0.04$ and $0.74 \pm 0.04$, respectively. On the other hand, the same study found out $10-15 \mathrm{~m}$ test value of rugby players, sprinters and active athletes as $0.63 \pm 0.03,0.63 \pm 0.03$ and $0.66 \pm 0.05$, respectively. A significant was also found between rugby players and sprinters in terms of group correlation (Dowson et al., 1998). Speed times of physical education students whose average years of age was $20.1 \pm 0.9$, height was $1.79 \pm 8.4 \mathrm{~cm}$ and weight was $74.5 \pm 9.8 \mathrm{~kg}(\mathrm{n}=24)$ were measured for $0-5 \mathrm{~m}, 5-10 \mathrm{~m}$ and $10-15 \mathrm{~m}$ distance ranges, and average time was measured as $1.86 \pm 0.06$ seconds for 5-10 m and as 2.60 \pm 0.10 for 10-15 m (Kukolj et al., 1999). A study found $10 \mathrm{~m}$ speed of 14 sub-elite male athletes as 1.7 seconds (Chaouachi et al., 2009). In a similar study, $10 \mathrm{~m}$ speed values of 16 male athletes were measured as 1.92 \pm 0.15 (Cochrane et al., 2004). Another study found speed values as $0.80 \pm 0.05$ for $5-10 \mathrm{~m}$ and as 
$0.72 \pm 0.05$ for $10-15 \mathrm{~m}$ (Gabbett et al., 2008). While speed is defined as the time that elapses in the first $10 \mathrm{~m}$, maximum speed time is defined as the time that elapses in $20 \mathrm{~m}$ (Little and Williams, 2005).

In conclusion, when the correlation between balanced and randomly selected somatotype groups of sub-elite athletes and their speed in $10 \mathrm{~m}$ and $20 \mathrm{~m}$ distance ranges is analyzed, it was observed that the speed of athletes who have balanced endomorph, mesomorph and ectomorph groups are fairly better than sub-elite athletes who have random endomorph, mesomorph and ectomorph groups, and that a highly positive correlation with a significance level of $\mathrm{p}<0.001$ was found between them. It can be argued that this results from differences of physical properties and sports branches.

\section{References}

Abe, T., S. Fukashiro, Y. Harada and K. Kawamoto, 2001. Relationship between sprint performance and muscle fascicle length in female sprinters. Journal of Physiological Anthropology and Applied Human Science, 2O(2): 141-147. View at Google Scholar $\mid$ View at Publisher

Carter, J.E.L., 2002. The heath-carter anthropometric somatotype-instruction manual. USA: San Diego.

Chaouachi, A., M. Brughelli, K. Chamari, G.T. Levin, N.B. Abdelkrim, L. Laurencelle and C. Castagna, 2009. Lower limb maximal dynamic strength and agility determinants in elite basketball players. Journal of Strength \& Conditioning Research, 23(5): 1570-1577. View at

Google Scholar | View at Publisher
Cochrane, D.J., S.J. Legg and M.J. Hooker, 2004. The short-term effect of whole-body vibration training on vertical jump, sprint, and agility performance. Journal of Strength \& Conditioning Research, 14(4): 828-832. View at Google Scholar $\mid$ View at Publisher

Delecluse, C., H.C. Van, E. Willems, M.L. Van, R. Diels and M.N.A. Goris, 1995. Influence of high-resistance and high-velocity training on sprint performance. Medicine and Science in Sports and Exercise, 27(8): 1203-1209. View at Google Scholar $\mid$ View at Publisher

Dowson, M.N., M.E. Nevill, H.K.A. Lakomy, A.M. Nevill and R.J. Hazeldine, 1998. Modelling the relationship between isokinetic muscle strength and sprint running performance. Journal of Sports Sciences, 16(3): 257-265. View at Google Scholar | View at Publisher

Gabbett, T.J., J.M. Sheppard, K.R. Pritchard-Peschek, M.D. Leveritt and M.J. Aldred, 2008. Influence of closed skill and open skill warm-ups on the performance of speed, change of direction speed, vertical jump, and reactive agility in team sport athletes. Journal of Strength \& Conditioning Research, 22(5): 1413-1415. View at Google Scholar | View at Publisher

Gambetta, V., 1996. In a blur: How to develop sport-specific speed. Sports Coach, 19(3): 22-24. View at Google Scholar

Hazır, T. and C. Açıkada, 2002. Reliability of bioelectric impedance analysis in assessing body composition: Comparison study. Journal of Sports Sciences, 13(2): 02-18.

Johnson, M. and J.G. Buckley, 2001. Muscle power patterns in the mid-acceleration phase of sprinting. Journal of Sports Sciences, 19(4): 263272. View at Google Scholar | View at Publisher

Kukolj, M., R. Ropret, D. Ugarkovic and S. Jaric, 1999. Anthropometric, strength, and power predictors of sprinting performance. Journal of Sports Medicine and Physical Fitness, 39(2): 120-122. View at Google Scholar

Little, T. and A.G. Williams, 2005. Specificity of acceleration maximum speed, and agility in professional soccer players. Journal of Strength and Conditioning Research, 19(1): 76-78. View at Google Scholar | View at Publisher

Marangoz, İ. and Ü. Özbalcı, 2017. Somatotype calculation program (SOMATOTÜRK). Journal of Academic Social Research (ASOS), 47(47): 288-293. View at Publisher

Marangoz, İ. and Y. Polat, 2017. Effects on body composition and somatotypes acceleration rate in male sportsmen. Journal of Academic Social Science, 54(5): 345-360.

Murphy, A.J., R.G. Lockie and A.J. Coutts, 2003. Kinematic determinants of early acceleration in field sport athletes. Journal of Sports Science \& Medicine, 2(4): 144-150. View at Google Scholar

Ross, A., M. Leveritt and S. Riek, 2001. Neural influences on sprint running. Sports Medicine, 31(6): 409-425. View at Google Scholar $\mid$ View at

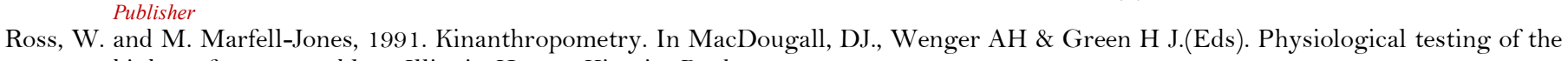
high-performance athlete. Illinois: Human Kinetics Books. pp: 223-308. 